Article

\title{
Caught between Paper Plans and Kashmir Politics: Disaster Governance in Ladakh, India
}

\author{
Jessica Field ${ }^{1,2}$ \\ ${ }^{1}$ Institute for Risk and Disaster Reduction, University College London, London, WC1E 6BT, UK; \\ E-Mail: jessica.field@ucl.ac.uk \\ 2 Jindal School of International Affairs, O.P. Jindal Global University, 131-001 Sonipat, India
}

Submitted: 14 April 2020 | Accepted: 27 June 2020 | Published: 10 December 2020

\begin{abstract}
Disaster governance encompasses the responsibility and management of disaster mitigation, relief and recovery as well as power and politics around these areas of action. Research on disaster governance focuses on various scales of action when examining the implications of disaster governance frameworks for particular populations and there is growing scholarship on the impacts that national politics and programmes have on local efforts. Under-represented in these discussions is an engagement with the relationality of disaster governance within national boundaries, not just vertically (i.e., the local in relation to the national) but horizontally - the local in relation to other locals. Through an examination of Ladakh in relation to neighbouring Kashmir, this article shows how local efforts to enhance disaster governance have been stymied both by the vertical (local-centre) politics of border security and conflict, as well as by the material effects that politics and violence in neighbouring Kashmir Valley have on Ladakh.
\end{abstract}

\section{Keywords}

conflict; disaster governance; Ladakh; local; Kashmir

\section{Issue}

This article is part of the issue "The Politics of Disaster Governance" edited by Dorothea Hilhorst (Erasmus University Rotterdam, The Netherlands), Kees Boersma (Vrije Universiteit Amsterdam, The Netherlands) and Emmanuel Raju (University of Copenhagen, Denmark).

(C) 2020 by the author; licensee Cogitatio (Lisbon, Portugal). This article is licensed under a Creative Commons Attribution 4.0 International License (CC BY).

\section{Introduction}

Disaster governance encompasses disaster risk reduction (DRR), mitigation, emergency response and recovery as well as knowledge production around these areas of action (Tierney, 2012). This term recognises the diverse set of state and non-state actors that are involved in disaster-related activities across the hazard cycle, and focuses attention on the messy intersection of wider societal governance frameworks with power, decisionmaking and politics during moments of crisis (Pal \& Shaw, 2018 , p. 4; Tierney, 2012, p. 342). As such, the term demands a highly contextualised look at the structural arrangements, processes and politics through which disaster risk, response and knowledge are shaped at various levels of societal governance.
Academic debates on disaster governance acknowledge the importance of attention to various scales of areas and actors (local, national, regional and international) when examining the implications of disaster governance frameworks for particular populations (Forino, Bonati, \& Calandra, 2018; Hilhorst, 2013; Lassa, 2010; Tierney, 2012). Most relevant to this article is the scholarly work on the subnational scale, which offers, typically, a close examination of disaster governance in one village/town/city/province, sometimes in relation to national-level power and politics, or else as a standalone study (for example, Heijmans, 2013; Kita, 2017). This literature explores how local political leaders and technocrats affect disaster risk while making everyday governance decisions-for example, over land use or funding allocations for public services. It also high- 
lights how businesses, non-profits and other local nongovernmental actors play a role in shaping knowledge and action around disasters (Bhatt, 2018, p. 32). In conflict zones, scholars have shown how a disaster can result in armed non-state and state actors taking on different enabling or obstructive roles on the ground, supporting or competing with national authorities (Hilhorst, Mena, van Voorst, Desportes, \& Melis, 2019; Hyndman, 2011; Walch, 2014). Under-explored in these discussions is the horizontal relationality of disaster governance within national boundaries. Namely, the local in relation to other locals.

Governance decisions in one local area by local and national actors may directly impact the disaster risk profile of its neighbour. Along these lines, there is growing scholarship on collaborative disaster management across local boundaries (Kapucu \& Hu, 2016; Kuo, Wang, Chang, \& Li, 2015); i.e., how neighbouring local governments and/or non-state actors work together to address a crisis that affects one or both regions. However, the extent to which governance decisions in neighbouring localities undermine or destabilise another's disaster governance policies or aspirations remains underexplored-leaving knowledge gaps around responsibility and accountability. This article seeks to address that gap with a case study focus on the disaster governance politics and processes of Ladakh, a remote region in India, as they have been affected by power and conflict politics in neighbouring Kashmir.

Ladakh and Kashmir are in a climatically-sensitive region of the Himalayas and have suffered significant recent disasters - a cloudburst in Ladakh in 2010 and floods in Kashmir in 2014. Both erstwhile divisions of Jammu and Kashmir (J\&K) state are also part of a wider conflict border zone, bordering Pakistan on the Kashmir side, and Pakistan and China for Ladakh. Moreover, both regions have a historically complex, although quite different, relationship with the state and central governments in Srinagar and Delhi. Ladakhi political narratives have long conferred a sense that Ladakh's governance aspirations have been thwarted by communal politics, development priorities and outbreaks of violence in Kashmir. This article explores those narratives in relation to disaster governance in Ladakh. It shows how Kashmir-related politics and conflict have continued to limit Ladakhi efforts to augment the region's disaster preparedness and mitigation, despite their separate disaster management structures and authority.

In short, this article uses a case study to call for closer attention to the ways that local territories are directly and indirectly connected to other local areas, and how these messy, overlapping (political) relations affect the disaster governance policies, programmes and aspirations in neighbouring locales. It is hoped that the lens of relationality can be applied in other contextsparticularly in situations of internal conflict, where conflict politics in one locale may spill over to affect the disaster risk and governance situation of a neighbouring area, even when the violence itself does not extend across internal boundaries. With this conflict backdrop, I also hope to contribute to discussions on the conflict-disaster nexus (Hilhorst, 2013; Hilhorst et al., 2019; Siddiqi, 2018; Venugopal \& Yasir, 2017; Walch, 2014), through highlighting new ways that conflict dynamics can contribute to hazard vulnerability.

To make these arguments, the article opens with an overview of data collection and a note on Ladakh's current governance context in light of recent changes. Then, to set the national scene, I offer a broad overview of disaster management in India and the disaster governance characteristics of other states. This is followed by an overview of the politics and hazard profile of Ladakh and, in Section 5, an analysis of how and why Ladakh's administration has failed to improve their disaster governance framework since the 2010 disaster. Section 6 then expands on the relational nature of disaster governance in Ladakh and examines future disaster risk, as it explains how Ladakh's hazard vulnerability is intricately bound up with conflict politics in Kashmir.

\section{Research Methods and a Note on Ladakh's Status}

Research for this article was conducted between 2017-2019 in Leh and Kargil (Ladakh's two districts), building on two funded projects. The first examined disaster resilience and governance in Ladakh and included 12 interviews with key figures linked to disaster governance through their leadership roles in disaster management and/or civil society: the then-Additional Deputy Commissioner (ADC) Leh, the then-Chief Executive Councillor of the Ladakh Autonomous Hill Development Council Kargil, two government officials from tourism in Leh and education in Kargil, two researchers that worked on the 2010 Leh District Disaster Management Plan and efforts to revise it, two leaders from local Muslim and Buddhist faith associations in Leh, three local NGOs' workers in Leh, and a journalist-activist in Kargil. Initial respondents-a researcher on the District Disaster Management Plan and local NGO workerswere sourced through personal contacts, and subsequent respondents were snowballed from there. The second project examined the governance of tourism and trade in Ladakh in relation to wider conflict politics and its remote, hazard-exposed location. For this project, colleagues and I undertook five interviews with leaders of different market trading associations in Leh who were snowballed from contacts established by our local research assistant. These interviews have been used to inform the article's wider analysis of everyday governance in relation to Ladakh's geographical remoteness and conflict politics. Finally, the analysis is also built on my experience of engaging with the Leh administration in Ladakh on the revision of their District Disaster Management Plan (DDMP; Leh District Administration [LDA], 2011). Colleagues from University College London and the University of Jammu and I hosted a series of 
workshops with the ADC of Leh and other officials in 2017 and 2019 (referred to hereafter as the 'DDMP consultations') and offered extensive feedback on how to improve the existing DDMP for Leh in 2019. Much of this article's analysis focuses on Leh district, as it was the worst affected by the 2010 floods and interviews centred heavily on the subsequent evolution of the Leh DDMP. As I briefly explain later, Kargil has different social and political dynamics that affect its own disaster governance within Ladakh. Nonetheless, this article retains its all-Ladakh frame, as many of the observations around disaster management plan development and the effects of conflict politics in neighbouring Kashmir are relevant to both districts.

During the course of this research, J\&K has undergone a significant governance transformation. Prior to February 2019, Leh and Kargil districts enjoyed a relative level of autonomy through their respective Ladakh Autonomous Hill Development Councils, although Ladakh as a whole fell under the administrative division of Kashmir. In February 2019, Ladakh gained divisional status alongside Kashmir and Jammu. Then, on 5 August 2019, the Indian government revoked the special status of the entire J\&K (protected under Article 370 of the Constitution) and passed a Bill reorganising it into two separate Union Territories (UT) of Jammu and Kashmir and Ladakh. While the details of the governance of the new UTs are still evolving, this status change has significantly reduced the autonomy of the erstwhile state. As the situation remains dynamic, this article focuses mainly on events from the 2010 cloudburst in Ladakh up until UT status implementation began in October 2019.

\section{Disaster Governance in India}

Disaster governance refers to the way society manages its disaster risks (Lassa, 2011, p. 114), and it calls attention to the diversity of actors involved in disaster-related activity, and the multiplicity of processes that affect disaster risk-economic, social and political (Tierney, 2012, p. 342). It departs from the concept of disaster management, which typically focuses on the narrower work of governments in relation to reducing disaster risk - through, legislation, planning and administration, for instance (Lassa, 2011; Tierney, 2012, p. 342). Moreover, the concept disaster governance gives space for the consideration of how actors and processes not directly concerned with disasters may work towards, or against, DRR goals. For instance, at the global scale, processes such as globalisation have impacted the limits and possibilities of disaster governance in many states as a result of their effects on economic organisation and political empowerment, particularly in the Global South (Tierney, 2012, p. 346). At a national/local scale, conflict politics can introduce new actors/dynamics or influence decision making in ways that undermine DRR and mitigation (Hilhorst, 2013). At local and individual scales, grassroots organisations or individuals them- selves may take responsibility for risk reduction activities, with or without consultation with government authorities. For instance, borrowing an example from Lassa (2010, p. 29), in earthquake-prone contexts where building codes are lacking or poorly enforced, homeowners may become individually responsible for deciding whether to build earthquake-resilient houses or not. These different scales and centres of authority in disaster governance often overlap and can complement, contradict, or compete with each other. Thus, distinctly different local disaster governance characteristics can emerge within a country that has a single overarching disaster management framework.

As noted in the introduction, academic work using the concept of disaster governance as a lens to explore the multi-centred nature of decision-making around disasters has grown significantly in the last decade (Lassa, 2010, 2011; Tierney, 2012; Walch, 2018), including in India (Field \& Kelman, 2018; Pal \& Shaw, 2018; Pramanik, 2017; Rautela, 2018). The need to acknowledge complexity in authority and decision making in disasters is also reflected in global policy through the Sendai Framework for DRR (SFDRR) 2015-2030, Priority 2: "Strengthening Disaster Risk Governance to Manage Disaster Risk" (UNDRR, 2015). This SFDRR priority recognises that the central government has the primary responsibility to reduce disaster risk, but that responsibility must also be taken by a variety of other stakeholders, including local government, the private sector, and civil society, among others.

In 2016, India was one of the first countries to align its National Disaster Management Plan with the Sendai Framework-though this was arguably just building on already-existing legislation with similar principles (Bhatt, 2018). Prior to the SFDRR, India's National Disaster Management Act, 2005, saw the formation of a National Disaster Management Authority and mandated state governments to establish State Disaster Management Authorities (SDMA). SDMAs were to be key disaster management nodes, ensuring ongoing risk governance, preparedness, and coordination in the event of a crisis (Sibal, 2020 , p. 18). Decentralisation was recognised as essential to the prevention, risk reduction and management of disasters (Sibal, 2020). Disaster Management Plans should have subsequently been developed at all levels (national, state, district) and the implementation of these plans should be supported by district authorities and city administrations, which retain a lot of authority in disaster situations. However, while India is leading the way globally in the bureaucratic implementation of Sendai Framework actions, its disaster governance is largely characterised by top-down management and uneven approaches to risk reduction at state and district levels.

Colin Walch (2018) has argued that Odisha's response to cyclone Phailin in 2013, where minimal lives were lost, is a strong example of effective decentralisation and collaboration across government networks and 
local actors. In this potentially catastrophic disaster, a severe cyclone hit the coast of Odisha causing destructive winds and flooding from a storm surge and torrential rainfall; it affected 11 million people, but only 23 lives were lost (Walch, 2018, p. 7). Odisha's success at keeping fatalities to a minimum is attributed to effective local DRR and preparedness measures implemented by the Odisha state government and local non-governmental actors - these were themselves built on lessons learned after a previous crisis. As Walch (2018) explains, the devastating 1999 Odisha cyclone provided a traumatic shock that catalysed the political leadership and local actors into new ways of thinking around risk reduction and preparedness. As a result, new institutions were created, including the Odisha State Disaster Management Authority-predating the SDMAs that followed the 2005 Disaster Management Act. These institutions promoted new and more flexible collaboration with segments of the population previously excluded, and a focus on preparedness and mitigation in addition to relief and recovery (Walch, 2018, pp. 7-8).

Elsewhere in the country, however, India has seen less success. In Uttarakhand in 2013, for instance, heavy rainfall caused landslides and floods that killed at least 6,000 people, as high rains coincided with an annual Hindu pilgrimage to Kedarnath (Ziegler et al., 2014). Though the annual monsoon had arrived earlier than usual and heavy rainfall was predicted by the national Indian Meteorological Department, the information was not effectively communicated to relevant actors on the ground and the state government moved too late to warn of floods. This failure at early warning intersected with an absence of building regulations, expansive illegal construction for the tourism industry, a spike in tourist migration as a result of the pilgrimage, and hydroelectric dam development that worsened the impact of the floodwaters (Dash \& Punia, 2019; Ziegler et al., 2014)ultimately resulting in significant damage and loss of life. These impacts speak of a governance tension at the state level between, on the one side, unsustainable tourism expansion and hydropower development for the economy and, on the other, the need for risk reduction and preparedness planning.

Similar tensions were evident in Ladakh in 2010, when a cloud burst and floods killed 257 people and caused significant damage to Leh town and nearby villages (Comptroller and Auditor General of India [CAG], 2016 , p. 1). Issues such as expansive tourism constructions in hazard-exposed areas and non-implementation of building codes exacerbated the scale of the 2010 disaster. Since then, Ladakh's officials and civil society have sought to learn from mistakes (DDMP consultations, July 8, 2019; Petterson et al., 2020). Unlike in the case of Odisha, however, Ladakh continues to struggle to improve disaster preparedness and risk reduction (Field \& Kelman, 2018; Le Masson, 2015). One aspect of this, as scholars have effectively highlighted elsewhere (Dame, Schmidt, Müller, \& Nüsser, 2019; Le Masson, 2015), is the continued expansion of the region's tourism sector and infrastructure that does not meet DRR standards. In addition to this, conflict politics across the border in Kashmir continue to affect power and decision making around DRR, mitigation and relief in Ladakh. The following section will offer a brief overview of the politics and hazard profile of $J \& K$, before examining in more detail how politics and conflict in a neighbouring region can affect DRR elsewhere.

\section{Hazard Risks and Disaster Responses in India's Contested Borderland}

Previously an independent Buddhist kingdom, Ladakh was incorporated into J\&K in the mid-19th century and remained within the state after Partition in 1947, making it a Buddhist-majority area nestled within a Muslimmajority state in India. Since Partition, J\&K has been a contested region between India and Pakistan, and has seen intra-state conflicts in 1947, 1965, 1971 and 1999. Ladakh's neighbour, Kashmir, has been the site of ongoing separatist protests and insurgency activity since 1987, which has resulted in recurrent clashes between Indian forces and insurgents and high civilian casualties (Staniland, 2013, p. 935). This conflict has resulted in a highly militarised army and police presence in Kashmir Valley, and the long Himalayan stretch of the border between India and Pakistan (and India and China) is closed. In addition to wars with Pakistan, India also fought-and lost-a war against China in 1962 and has experienced several border confrontations and incursions since then (Field \& Kelman, 2018), with the most serious occurring at the time of writing, beginning May 2020. Since 1962, Ladakh has had a permanent stationing of the Indian army across the region, and Ladakhi relations with the Indian army are broadly positive (Field \& Kelman, 2018)-a direct contrast with Kashmir, whose residents largely see the military as an occupying force (Venugopal \& Yasir, 2017). While Kashmir has remained open to domestic and visa-holding visitors, Ladakh was closed off entirely to most foreigners and nationals until 1974 when it was partially re-opened to encourage tourism. Both divisions are now heavily reliant on the tourist economy.

Until February 2019, Ladakh was not its own division within J\&K but fell under the authority of Kashmir division. Since at least the late 1950s, public figures in Ladakh have articulated a sense of discrimination they felt in the J\&K State Assembly as a result of this subordinate arrangement-in terms of political representation, allocation of funds and development support (Rizvi, 2011, p. 94; Shakspo, 2017, p. 73, p. 132). Of the 89 seats available in the J\&K State Assembly prior to 2019, Ladakh had four, which had been criticised as insufficient by Ladakhi figures for decades. Moreover, Ladakh can still only send one MP to Delhi. These criticisms of poor representation had (and continue to have) anti-Kashmir and communal tones, as many Ladakhis 
have framed and experienced marginalisation in geopolitical and faith terms: a Buddhist-majority region being overlooked by a Muslim-majority division (Kashmir) in a Muslim-majority state (J\&K) (van Beek, 2004, p. 196). Between 1989 and 1993 communal tensions morphed into confrontation as Buddhist groups in Leh turned their frustration against the Kashmir administration towards the Muslim-minority population within Ladakh, sparking violence and boycotts (van Beek, 2000). The conflict was diffused with the creation of the Ladakh Autonomous Hill Development Councils of Leh in 1995 and Kargil in 2003 , which has given the region a level of autonomy in economic development, education, healthcare, land use and other areas. Nonetheless, Ladakh's state-level subordination to Kashmir has continued to contribute to a general feeling of remoteness and discrimination-themes which will be picked up again shortly.

In terms of hazard risks, Ladakh and Kashmir are situated in seismic zones $\mathrm{VI}$ and $\mathrm{V}$ respectively (the highest earthquake risk categories), and the entire erstwhile state of J\&K is prone to a variety of hazards. During winter, intense snowfall can cut off access roads to the region for months (LDA, 2011). Avalanches and landslides are commonplace and, across summer and early autumn, Ladakh is at high risk of flooding (Dame et al., 2019; LDA, 2011; Le Masson, 2015). The cloud burst and floods in August 2010, the peak of tourist season, came as a shock to both residents and the administrationand the responses were deemed inadequate (Interviews, faith leaders, June 3, 2017; Interview, Ladakhi studentresearcher, June 2, 2017). Debris-ridden flood water gushed through main thoroughfares in Leh, Ladakh's urbanised capital, and nearby villages, destroying communication infrastructure, businesses and homes (Field \& Kelman, 2018). Local services were overwhelmed during the crisis and the response was characterised by poor coordination and communication between the military, Ladakh administration, and local groups (Field \& Kelman, 2018 , p. 650). From the perspective of many locals, the army offered welcome relief during the emergency phase of the crisis, though this occurred largely in parallel to ad hoc civilian relief efforts rather than in coordination with them (Interviews, faith leaders, June 3, 2017). Prior to the event, mitigation strategies were largely absent across Ladakh and much of the damage occurred in hazard-exposed areas (Le Masson, 2015). A number of bureaucratic, political and economic factors intersected to exacerbate the negative impact of the floods and these continue to hamper risk reduction and mitigation, despite local efforts to improve disaster governance.

\section{Disaster Governance Plans and Politics in Ladakh}

The central and state governments had undertaken little in the way of DRR and preparedness in Ladakh prior to the 2010 cloudburst-not least because of the reactive, hazard-centred approach that characterises much of the country's disaster governance (Le Masson, 2015).
Moreover, because of Ladakh's strategic location on the borders of both Pakistan and China, 'New Delhi, together with the state capital, Srinagar, [have become] involved at every level of socioeconomic policies related to the “development" of Ladakh' (Le Masson, 2013, p. 127). Key to the region's economic and political development is tourism. The tourism industry has not only become a central economic lifeline for the region since it opened to visitors in 1974, it has also become an important "flag planting" activity encouraged by the centre in Delhi, as it serves to clearly mark the contested area as part of India (Norberg-Hodge, 1991, p. 92; Vogel \& Field, 2020, p. 4). The government has 'single-mindedly push[ed] tourism as the cornerstone of the "Ladakh" they are imagining,' noted an editorial in a popular Ladakhi magazine recently (Ghosal, 2019). This has resulted in a rapid urbanisation of Ladakh's towns and villages. Illegal tourism-related constructions in flood-prone areas and the proliferation of poor-quality infrastructure has rendered the population in Ladakh highly vulnerable to and exposed to hazards (as well as everyday disasters, such as contaminated water and pollution; Dame et al., 2019).

Moreover, as Field and Kelman (2018) have highlighted, border conflict politics and the resultant permanent stationing of the military in Ladakh has led the army to take a leading role in disaster management. This has cemented a hazard-centred, command-and-control approach to disaster management, exacerbating local dependency on the military and underinvestment in community preparedness and planning (Pramanik, 2017, p. 192). In strategic areas at the national border-limits of Ladakh, security priorities have also limited data gathering/sharing about community vulnerabilities. External NGOs struggle to gain central government permissions to operate in the area altogether, limiting disaster-related knowledge exchange (Field \& Kelman, 2018).

Following the impacts of the 2010 disaster, a District Disaster Management Plan for Leh was launched in 2011 and officials have been undertaking consultations in the last few years in order to update it, recognising the limitations of this first version (Interview, ADC Leh, June 8, 2017). Interestingly, this district-level document preceded a state-level template. J\&K approved its first-ever State Disaster Management Plan (SDMP) only in 2015 (Rising Kashmir, 2015). This was prepared by the Tata Institute of Social Sciences-who had earlier been consulted about supporting the development of an SDMP after Kashmir experienced an earthquake in 2013, but the project saw limited movement until Kashmir's devastating 2014 floods (Rising Kashmir, 2015). Since then, a flurry of DDMPs have been produced for Kashmir districts, too.

A disaster management plan does not itself guarantee effective disaster governance. These bureaucratic documents form only one part of a wider development and disaster governance eco-system. Also, to be useful, paper schemes require quality content, such as a factual evidence base, goals and objectives, and 
an effective strategy and tools for implementation and evaluation (Kim \& Marcouiller, 2018). The 2011 Leh DDMP (LDA, 2011) is not a 'quality' plan in that sense. It is hazard-centred and lacks any analysis of socioeconomic vulnerability and capacity (Le Masson, 2015, p. 107). Moreover, a central government audit of J\&K disaster capacity in 2016 noted that it had still yet to be implemented or reviewed (CAG, 2016). The Leh DDMP, like many of the State and DDMPs across India, is characterised by a command-and-control approach to disasters-focused on reaction rather than mitigation and preparedness (Field \& Kelman, 2018; Pramanik, 2017 , p. 192). Nonetheless, its publication and subsequent efforts to revise it indicate a commitment to augment the region's disaster governance. Moreover, Leh's ADC from 2016-2019 took particular leadership in this endeavour. The ADC, a senior figure in Ladakh's governance, supported the development of the 2011 plan while in a different administrative role, and spearheaded the revision of the 2011 version when he took over as ADC in 2016-mobilising local research resources and engaging in numerous consultations (Interview, ADC, June 8, 2017; DDMP consultation, July 8, 2019). Notably, Kargil district did not develop its own DDMP until 2017highlighting an imbalance of disaster governance activity within Ladakh itself.

Following the 2010 floods, Ladakh civil society also mobilised to augment local capacity and resilience: officials and locals hosted DRR workshops on multiple occasions post-2010 (Ahmed et al., 2019; Johnson, 2014; Petterson et al., 2020); the Ladakh Ecological Development Group (LEDeG) rebuilt some of the destroyed buildings using earthquake-resistant designs (Le Masson, 2015, p. 108; SEEDS India \& LEDeG, 2010); and Leh Nutrition Partnership (LNP) supported the design and construction of new schools following DRR principles (Interview, LNP, June 7, 2017; Le Masson, 2015, p. 108). However, these initiatives were primarily directed by local NGOs in collaboration with national or international civil society partners - for instance, LEDeG worked with SEEDS India, and LNP with Save the Children India. As such, they were discreet projects with time and finance limitations, disconnected from wider governance systems such as urban planning and development. Local community leaders noted there continued to be an absence of any sustained DRR-related activity (Interview, faith leader, June 3, 2017). This was a result, partly, of local bureaucratic inertia, but it has also been affected by Ladakh's actual and perceived marginalisation within J\&K governance.

Taking the first point of bureaucratic inertia, the Ladakh administration has suffered a lack of state investment in disaster-related capacity. The central government audit of J\&K disaster capacity noted in 2016 that District Disaster Management Authorities-boards of local officials and experts responsible for disaster management planning and coordination-had yet to be established across J\&K (CAG, 2016, p. 5). While Leh's ADC took personal responsibility for reviewing and updating the 2011 Leh DDMP, this was done in and around his dayto-day governance responsibilities for Ladakh. Interviews and DRR-related meetings I conducted with local civil society organisations and government officials in Leh during the summers of 2017 and 2019 suggested that the sustainability of DRR activities was still frustrated by a lack of systematic coordination. An official from the Tourism Department of the Ladakh Autonomous Hill Development Council Leh noted that, although mock evacuation drills had recently started, 'we need a disaster management unit here' (Interview, LAHDC Official, June 3,2017$)$. The director of the LNP also remarked that there continues to be, 'no DRR forum for Ladakhi organisations to share ideas. Only a cluster in the immediate aftermath of 2010' (Interview, LNP, June 7, 2017).

The Ladakh administration's inconsistent attention to disaster-related matters beyond the drawn-out development of management plans can be understood partly through Indian bureaucracy's tendency to deal with future risk by materialising scientific and technical expertise through the production of documents rather than action (Gagné, 2019, p. 844; Mathur, 2014). However, this inertia was also exacerbated by poor support from state and central government. State level funds earmarked for both the establishment of an Emergency Operation Centre and multi-hazard risk mapping at a district level were not utilised in Ladakh or other districts in J\&K (CAG, 2016, p. vi). The ADC Leh remarked in a 2017 interview that he was not aware of DRR funds available within the state that Ladakh could utilise (Interview, ADC, June 8, 2017). A local NGO worker remarked that, 'huge money is given to the states by the centre for disaster mitigation, [but] the money for J\&K is often returned to the centre' because it is unused (Interview, LNP, June 7, 2017). Moreover, what is notable in the timeline of disaster plan productions outlined above is that the development of Leh's DDMP came without a statelevel foundation-despite both being mandatory under the National Disaster Management Act of 2005. The J\&K government did not seek to develop any State Disaster Management Plan or division-level guidance around disaster governance in response to Ladakh's 2010 disaster; rather, it took two consecutive crises in Kashmir to kickstart a review and plan. Such oversight has materially contributed to the underdevelopment of Ladakh's disaster governance (at least in terms of paper plans), but it also characterises a historic neglect or discrimination that Ladakhis have felt by the administration in Kashmir, which has its own implications for disaster vulnerability.

\section{Ladakh in Relation to Kashmir: Conflict Politics}

Trust relations between a population, civil society and the government play a central part in reducing disaster risk. Poor State-civil society relations can result in fragmented or duplicative responses and risk reduction activities (Tierney, 2012, p. 351). A lack of trust between citizens and their government, or a feeling of 
discrimination, can result in populations ignoring early warnings, refusing to take part in mitigation activities and diminishing returns on recovery activities (Forino et al., 2018, p. 1; Sandoval \& Voss, 2016, p. 114). Karine Gagné's (2019) study of the 2015 Phuktal floods offers an important example of how a sense of discrimination in Ladakh by the government in J\&K has spilled into disaster governance and vulnerability. When a threat of a natural dam burst and a subsequent flood was facing the Buddhist region of Zanskar in the Muslimmajority district of Kargil, the state and central government's (mis)management of mitigation and evacuation was viewed through the lens of historic communal discrimination, as well as 'the incompetence of the state and its disregard for local concerns' (Gagné, 2019, p. 848). The J\&K government imposed mobility restrictions on the Zanskar population in order to reduce hazard risk. These restrictions were the same as those imposed during the 1989 communal agitations when the state government attempted to quell Ladakhi Buddhist agitations against Ladakhi Muslims-an observation that was not lost on Zanskar residents. This communal backdrop, Gagné (2019, p. 843) argues, exacerbated mistrust in the government's disaster mitigation activities and augmented vulnerability, as it affected the way that the Zanskar community received and interpreted communications from J\&K about the disaster risks they faced.

Mistrust in Srinagar-based authorities is widespread in Ladakh, as Ladakhis have read other restrictive measures undertaken by J\&K and the central government as part of a wider agenda of neglect or discrimination. When there is a spike in violence (or potential violence) in Kashmir or Jammu, the government implements repressive measures-some of which affect Ladakh. In August 2013, for instance, the Internet was suspended for five days in Ladakh, along with the rest of J\&K, following Muslim-Hindu communal riots in Kishtwar, in Jammu (Press Trust of India, 2013). More recently, following the UT status announcement in August 2019, Kashmir and parts of Ladakh had their Internet cut for an extended period-including 145 days in Kargil (Internet Shutdowns, 2020). While these two communication cuts are known to be externally imposed, interviews and online discussions in Ladakh have intimated suspicion that other more frequent (though typically much shorter), drops in the Internet are also connected to violence and politics in Kashmir, despite Ladakh's disconnect from Kashmir's separatist politics. One Facebook user on a popular online forum-'Ladakh in the Media'commented on a 2017 post by political leader N. Rigzin Jora, that: 'Since [the] Kashmir mass uprising, all Wimax connections were suspended [in Ladakh] almost for more than three months' (Wangail, 2017). It is perceived that these cuts are used either as a means to prevent dissent spreading (Interview, Ladakhi student-researcher, June 2 , 2017), or they are seen as part of state-level efforts to keep Ladakh marginalised. Facebook user Mohd Hussain echoed many similar posts on the 'Ladakh in the Media' group about weak communication infrastructure when he commented on a different 2017 post by a local activist: 'Now, the broken connection in zojilla area is a big joke in 21st century. The state as well as the centre [are] always discriminating [against] the ladakhis' (Hussain, 2017; see also similar comments on Wangail, 2017). These forums provide important means for Ladakhis to speak directly to political leaders and voice their concerns about political issues-and such comments underline an ongoing mistrust in the state and a sense that Kashmir politics directly affects Ladakh's material wellbeing. As highlighted in relation to the Phuktal floods, mistrust can entrench power (or a sense of powerlessness) and can reproduce or exacerbate existing inequalities (Forino et al., 2018, p. 1).

Beyond issues of trust, disrupted communication also presents a material disaster risk factor. Disaster governance-indeed everyday governance-benefits from working and accessible communication for early warning and general information (Rautela, 2018, p. 178; Toya \& Skidmore, 2018, p. 2). As Cutter, Boruff, and Shirley (2003, p. 245) have argued, a lack of access to resources, including information, knowledge and technology, are 'major factors' that affect social vulnerability to hazards. Phone and Internet infrastructure enable residents to access risk-related information, to connect to each other (their local socio-economic safety-nets) and also to communicate with their government (for accountability) - all of which are prevented through communication shutdowns. A recent study of DRR awareness among students in Ladakh indicated their earthquake and landslide risk knowledge came primarily from the Internet and television media (Petterson et al., 2020, pp. 273-274). Frequent Internet cuts risk disrupting key information channels. While some communication challenges in Ladakh are a consequence of its remote location in the Himalaya, the cuts in August 2013 and 2019 were due to state intervention to quell protest or violence. Moreover, Ladakhi frustration around what they perceive is deliberate marginalisation may affect the way they receive and interpret future disaster risk information from external authorities.

Conflict politics in Kashmir have also negatively impacted Ladakh's economy, which may heighten hazard vulnerability through its knock-on effect on the ability of Ladakhis to withstand shocks. In February 2019, for instance, a Kashmiri youth killed more than 40 Indian army soldiers in a suicide attack in the Kashmir's Pulwama district. In response, the central government temporarily closed J\&K's National Highway 44 in April 2019 for two days a week-a vital transport artery for Ladakh for goods and tourists. Security scares such as these frequently contribute to drops in tourism for Ladakh-both as a result of tourists' safety fears, and road closures that prevent tourists from arriving there. During fieldwork in Leh in the summer of 2019, interviews and media reports suggested visitor numbers had dropped as much as $50 \%$ compared with the 
previous year, and many attributed this to a combination of Pulwama-related security concerns, road closures, national elections and the collapse of a major airline serving Leh (Interview, market trader, September 6, 2019; Press Trust of India, 2019). Going further back, Sunetro Ghosal (2019, p. 5) analysed data from the Tourism Departments in Leh and Kargil and noted that significant drops in tourist numbers over the last three decades broadly tallied with conflict events over the border: i.e., in 1990 following increased militancy in Kashmir; in 1999 as a result of war with Pakistan; in 2008 following a land transfer controversy and mass protests in Kashmir Valley; and in 2016 after a spike in unrest in Kashmir. Kargil is particularly affected by these events as it is much more reliant on tourist entries via the road from Srinagar (whereas Leh has an airport), though many households across Ladakh are reliant on tourism for their income (Vogel \& Field, 2020). Economic insecurity affects the capacity of these households to 'anticipate, cope with, resit and recover from the impact of a natural hazard' (Wisner, Blaikie, Cannon, \& Davis, 2003, p. 11). However, because such shocks result from a conflict for which Ladakh is not directly a party, opportunities for Ladakhis to anticipate disruption or contribute to mitigating the effects of the conflict-disaster nexus are constrained.

Since UT status came into force on 31 October 2019, Kashmir and J\&K state have now been removed as intermediary authorities in Ladakh's governance system, as the UT of Ladakh now falls under Delhi. However, it is not clear at the time of writing whether that will result in a tangible decentralisation of power and resources to Ladakhis, or perhaps even a further loss of power to the centre, as much is still under consideration (Lundup \& Fazily, 2020). Moreover, while Leh was more broadly welcoming of UT status, residents in Kargil have strong faith-linkages and road/trade connections with Kashmir-resulting in divided opinion over the benefits of UT to Ladakh as a whole (Vogel \& Field, 2020). This tension demands a look at the relational politics of disaster governance within Ladakh itself.

In terms of disaster governance for Ladakh in relation to Kashmir, what UT status has changed is the immediate relevance and utility of Leh and Kargil's DDMPs. Indeed, much of the reporting and governance information in these plans is now obsolete. UT also has implications for disaster leadership, as government officials have been shuffled around to different positions in this new political territory. The ADC of Leh who took personal responsibility for the Leh DDMP revisions has now been promoted into a different role overseeing urban local bodies, industry and commerce. What UT has not changed is Ladakh's geographical and historical ties to Kashmir and wider J\&K, and the complex interaction of security and development across the two locales. As such, there is the possibility of continued Internet black outs, road closures, fluctuations in tourism and a sense of marginalisation caused by politics, policies and conflict in Kashmirall of which may heighten future hazard vulnerability.

\section{Conclusion}

Disaster-related power relations and politics are not neatly contained within geopolitical boundaries; they are affected by actions, events and politics that transcend borders in messy and non-liner ways. While disaster governance literature explores how local contexts are affected by national and international power and politics, less explored is how local contexts can be affected by power and politics in neighbouring locales. Taking up this issue, this article has analysed Ladakh's disaster governance in relation to neighbouring Kashmir.

Firstly, I examined the disaster-related inequalities and vulnerabilities that have arisen in Ladakh as a result of its power relations with J\&K State and the government in Delhi. Local narratives and experiences of political marginalisation by Kashmir within J\&K have developed anti-Kashmir and communal tones-resulting in violence in 1989, and an ongoing trust deficit that was, until governance changes in 2019, characterised by a sense of powerlessness within regional political structures. Mistrust in authorities in Kashmir and Delhi heightened hazard vulnerability in relation to the 2015 Phuktal floods (Gagné, 2019), and risks exacerbating vulnerability in the face of future hazards, as many Ladakhis have long attributed the region's underdevelopment to a Kashmir-linked agenda of deliberate marginalisation. In addition, Ladakh's disaster risk profile has been materially affected by conflict politics in Kashmir and Jammu. Ladakh has faced frequent communication black outs, road closures and drops in tourist numbers (on whom they rely for economic stability)-heightening hazard vulnerability.

These are not the only factors affecting disaster risk in Ladakh. Similar to Uttarakhand in 2013, illegal tourism expansion and poor enforcement of building standards across Ladakh continue to exacerbate hazard risks (Dame et al., 2019). However, through taking a relational perspective and examining Ladakh's disaster management aspirations as they have been affected by Kashmir, this article has shown that effective disaster governance at the local scale is not just contingent on programmes and policies developed by actors rooted in one context. It is also conditional on conducive politics and policies in neighbouring territories whose history and politics may be bound together in direct and indirect ways. While this article has focused on one single case study, it is hoped that a relational perspective can be applied to examine disaster governance in other contexts-particularly in situations where conflict politics in one area may affect the disaster risk and governance situation of a neighbouring locale.

\section{Acknowledgments}

I would like to thank Moses Kunzang and Stanzin Yougzeng for their continued support in Ladakh, Tsering Jolden and Tenzin Dolma for their invaluable research assistance, and Birte Vogel for her project support and 
such helpful comments on early drafts of the article. I also extend sincere thanks to the peer reviewers of this article whose feedback improved it immensely. Errors remain my own. This article was supported by two grants: Increasing Resilience to Environmental Hazards in Border Conflict Zones, National Environment Research Council NE/P016138/1 (2017-2019); and Trade for Peace in the Remote Himalaya, University of Manchester, Humanities Strategic Investment Fund (2018-2019).

\section{Conflict of Interests}

The author declares no conflict of interests.

\section{References}

Ahmed, B., Sammonds, P., Saville, N. M., Le Masson, V., Suri, K., Bhat, G. M., . . . Thusu, B. (2019). Indigenous mountain people's risk perception to environmental hazards in border conflict areas. International Journal of Disaster Risk Reduction, 35, 101063.

Bhatt, M. R. (2018). Disaster risk reduction: The Indian landscape. In I. Pal \& R. Shaw (Eds.), Disaster risk governance in India and Cross Cutting issues (pp. 23-28). Singapore: Springer Nature Singapore.

Comptroller and Auditor General of India. (2016). Report of the comptroller and auditor general of India on performance audit of disaster management in the state of Jammu and Kashmir (Report No. 4). Srinagar: Government of Jammu and Kashmir.

Cutter, S., Boruff, B., \& Shirley, W. (2003). Social vulnerability to environmental hazards. Social Science Quarterly, 84(2), 242-261.

Dame, J., Schmidt, S., Müller, J., \& Nüsser, M. (2019). Urbanisation and socio-ecological challenges in high mountain towns: Insights from Leh (Ladakh), India. Landscape and urban planning, 189, 189-199.

Dash, P., \& Punia, M. (2019). Governance and disaster: Analysis of land use policy with reference to Uttarakhand flood 2013, India. International Journal of Disaster Risk Reduction, 36. https://doi.org/10.1016/ j.ijdrr.2019.101090

Field, J., \& Kelman, I. (2018). The impact on disaster governance of the intersection of environmental hazards, border conflict and disaster responses in Ladakh, India. International Journal of Disaster Risk Reduction, 31, 650-658.

Forino, G., Bonati, S., \& Calandra, L. M. (Eds.). (2018). Governing risks, hazards and disasters: Trends in theory and practice. London: Routledge.

Gagné, K. (2019). Waiting for the flood: Technocratic time and impending disaster in the Himalayas. Disasters, 43(4), 840-866.

Ghosal, S. (2019). From the editor: A tale of two graphs. In S. Ghosal (Ed.), Stawa (p. 5). Leh-Ladakh: Stawa.

Heijmans, A. (2013). Chapter 13: The everyday politics of disaster risk reduction in Central Java, Indonesia. In D. Hilhorst (Ed.), Disaster, conflict and society in crises:
Everyday politics of crisis response (pp. 223-239). Oxon: Routledge.

Hilhorst, D. (Ed.). (2013). Disaster, conflict and society in crises: Everyday politics of crisis response. Oxon: Routledge.

Hilhorst, D., Mena, R., van Voorst, R., Desportes, I., \& Melis, S. (2019). Disaster risk governance and humanitarian aid in different conflict scenarios. The Hague: International Institute of Social Studies, Erasmus University Rotterdam. Retrieved from https://www.unisdr.org/files/65903_f303hillhorst disasterresponseandhum.pdf

Hussain, M. (2017). When did the bsnl gived proper service to the ladakhis. In Kargil very poor service when bsnl came in service [Facebook comment on the January 28, 2017, post by Tsewang Rigzin]. Retrieved from https://www.facebook.com/groups/ 904515826309195/permalink/1297925656968208

Hyndman, J. (2011). Dual disasters: Humanitarian aid after the 2004 tsunami. Sterling, VA: Kumarian Press.

Internet Shutdowns. (2020). Homepage. Internet Shutdowns. Retrieved from https://internetshutdowns.in

Johnson, K. (2014). Learning in Leh: Workshop in India, 2011 (Report). London: Architecture Sans Frontières. Retrieved from http://www.asf-uk.org/wpcontent/uploads/2016/05/ASF20Leh20Report20 Full_final.pdf

Kapucu, N., \& Hu, Q. (2016). Understanding multiplexity of collaborative emergency management networks. The American Review of Public Administration, 46(4), 399-417.

Kim, H., \& Marcouiller, D. W. (2018). Mitigating flood risk and enhancing community resilience to natural disasters: Plan quality matters. Environmental Hazards, 17(5), 397-417.

Kita, S. M. (2017). “Government doesn't have the muscle": State, NGOs, local politics, and disaster risk governance in Malawi. Risks, Hazard \& Crisis in Public Policy, 8(3), 244-267.

Kuo, M., Wang, C., Chang, Y., \& Li, T. S. (2015). Collaborative disaster management: Lessons from Taiwan's local governments. In Y. Jing (Ed.), The road to collaborative governance in china: Governing china in the 21st century. New York, NY: Palgrave Macmillan.

Lassa, J. (2010). Institutional vulnerability and governance of disaster risk reduction: Macro, meso and micro scale assessment (Unpublished Doctoral dissertation). Friedrich Wilhelms, University, Bonn, Germany.

Lassa, J. (2011). Disaster governance. In K. B. Penuel \& M. Statler (Eds.), Encyclopaedia of disaster relief (Vol. 1, pp. 114-114). Thousand Oaks, CA: SAGE.

Leh District Administration. (2011). District disaster management plan, Leh District. Leh-Ladakh: Deputy Commissioner Office.

Le Masson, V. (2013). Exploring disaster risk reduction and climate change adaptation from a gender perspective: Insights from Ladakh, India (Unpublished 
Doctoral dissertation). School of Health Sciences and Social Care, Brunel University London, UK.

Le Masson, V. (2015). Considering vulnerability in disaster risk reduction plans: From policy to practice in Ladakh. Mountain Research and Development, 35(2), 105-115.

Lundup, T., \& Fazily, M. (2020). UT Ladakh's governance puzzle. In S. Ghosal (Ed.), Stawa (pp. 6-7). LehLadakh: Stawa.

Mathur, N. (2014). The reign of terror of the big cat: Bureaucracy and the mediation of social times in the Indian Himalaya. Journal of the Royal Anthropological Institute, 20, 148-165.

Norberg-Hodge, H. (1991). Ancient futures: Learning from Ladakh. Delhi: Oxford India Paperbacks.

Pal, I., \& Shaw, R. (Eds.). (2018). Disaster risk governance in India and cross cutting issues. Singapore: Springer.

Petterson, M., Nanayakkara, L., Konchok, N., Norman, R., Wangchuk, S., \& Linderoth, M. (2020). Interconnected geoscience applied to disaster and risk: Case study from SECMOL, Ladakh, N. India. Disaster Prevention and Management, 29(3), 266-286.

Pramanik, R. (2018). Armed forces in disaster response: Problems and perspectives on disaster governance in India. In G. Forino, S. Bonati, \& L. M. Calandra (Eds.), Governance of risk, hazards and disasters (pp. 190-205). Oxon: Routledge.

Press Trust of India. (2013, August 11). Mobile Internet services suspended in Jammu and Kashmir. The Economic Times. Retrieved from https:// economictimes.indiatimes.com/news/politics-andnation/mobile-internet-services-suspended-injammu-and-kashmir/articleshow/21759366.cms

Press Trust of India. (2019, June 25). Leh tourism drops by 50 percent in 2019: Jet Airways, Lok Sabha polls to blame. India Today. Retrieved from https:// www.indiatoday.in/lifestyle/travel/story/lehtourism-drops-by-50-per-cent-in-2019-jet-airwayslok-sabha-polls-to-blame-1555462-2019-06-25

Rautela, P. (2018). Lessons learned from 16/17 June 2013 disaster of Uttarakhand, India. In I. Pal \& R. Shaw (Eds), Disaster risk governance in India and cross cutting issues (pp. 165-1s92). Singapore: Springer.

Rising Kashmir. (2015, August 1). Mufti approves JK's first-ever disaster management plan. Rising Kashmir. Retrieved from http://www.risingkashmir.com/ news/mufti-approves-jks-firstever-disastermanagement-plan

Rizvi, J. (2011). Ladakh: Crossroads of high Asia (9th ed.). Oxford: Oxford University Press.

Sandoval, V., \& Voss, M. (2016). Disaster governance and vulnerability: The case of Chile. Politics and Governance, 4(4), 107-116.

SEEDS India, \& LEDeG. (2010). Shelter strategy: Leh Flood (Report). Delhi and Leh: SEEDS India.

Shakspo, S. W. (2017). Kushok Bakula Rinpoche: The architect of modern Ladakh. Delhi: Sonam Wangchuk
Shakspo.

Sibal, R. S. (2020). Are you prepared for a disaster? Mitigation and management of disasters. Delhi: Bloomsbury India.

Siddiqi, A. (2018). Disasters in conflict areas: finding the politics. Disasters, 42(S2), S161-S172.

Staniland, P. (2013). Kashmir since 2003: Counterinsurgency and the Paradox of "Normalcy". Asian Survey, 53(5), 931-957.

Tierney, K. (2012). Disaster governance: Social, political, and economic dimensions. Annual Review of Environment and Resources, 37, 341-363.

Toya, H., \& Skidmore, M. (2018). Cellular telephones and natural disaster vulnerability. Sustainability, 10(9), 2970.

UNDRR. (2015). Sendai framework for disaster risk reduction 2015-2030. Geneva: UNDRR. Retrieved from https://www.undrr.org/publication/sendaiframework-disaster-risk-reduction-2015-2030

van Beek, M. (2000). Beyond identity fetishism: "Communal" conflict in Ladakh and the limits of autonomy. Cultural Anthropology, 15(4), 525-569.

van Beek, M. (2004). Dangerous liaisons: Hindu nationalism and Buddhist radicalism in Ladakh. In S. P. Limaye, M. Malik, R. G. Wirsing (Eds.), Religious radicalism and security in South Asia (pp. 193-218). Honolulu, HI: Asia Pacific Centre for Security Studies.

Venugopal, R., \& Yasir, S. (2017). The politics of natural disasters in protracted conflict: The 2014 flood in Kashmir. Oxford Development Studies, 45(4), 424-442.

Vogel, B., \& Field, J. (2020). (Re)constructing borders through the governance of tourism and trade in Ladakh, India. Political Geography, 82, 102226. https://doi.org/10.1016/j.polgeo.2020.102226

Walch, C. (2014). Collaboration or obstruction? Rebel group behaviour during natural disaster relief in the Philippines. Political Geography, 43, 40-50.

Walch, C. (2018). Adaptive governance in the developing world: Disaster risk reduction in the State of Odisha, India. Climate and Development, 11(3), 238-252. https://doi.org/10.1080/17565529.2018.1442794

Wangail, T. (2017). Since Kashmir mass uprising, all Wimax connections were suspended almost for more than three months. Which has compelled all wimax [Facebook comment on the January 23, 2017, post by N Rigzin]. Retrieved from https://www.facebook. com/groups/904515826309195/permalink/1291073 837653390/?comment_id=1293505600743547

Wisner, B., Blaikie, P., Cannon, T., \& Davis, I. (2003). At risk: Natural hazards, people's vulnerabilities and disasters (2nd ed.). London: Routledge.

Ziegler, A. D., Wasson, R. J., Bhardwaj, A., Sundriyal, Y. P., Sati, S. P., Juyal, N., . . . Saklani, U. (2014). Pilgrims, progress, and the political economy of disaster preparedness: The example of the 2013 Uttarakhand flood and Kedarnath disaster. Hydrological Processes, 28(24), 5985-5990. 


\section{About the Author}

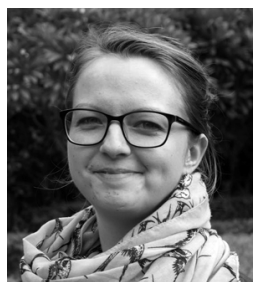

Jessica Field (PhD) is a Lecturer in Humanitarian Studies at the Institute for Risk and Disaster Reduction at University College London and an Adjunct Associate Professor at Jindal School of International Affairs, O.P. Jindal Global University, India. Her research interests include disaster governance, refugee protection and assistance-particularly in South Asia past and present. She recently coedited The Global Compact on Refugees: Indian Perspectives and Experiences (UNHCR \& AWG, 2020). 